\title{
Comments on Jonathan Lear's Radical Hope (Harvard: 2006)
}

\author{
Hubert L. Dreyfus
}

Published online: 28 March 2009

(C) The Author(s) 2009. This article is published with open access at Springerlink.com

\begin{abstract}
Cultural devastation, and the proper response to it, is the central concern of Radical Hope. I address an uncertainty in Lear's book, reflected in a wavering over the difference between a culture's way of life becoming impossible and its way of life becoming unintelligible. At his best, Lear asks the radical ontological question: when the cultural collapse is such that the old way of life has become not only impossible but retroactively unimaginable, - when nothing one can do (or did) makes sense anymore, - how can one go on? In raising this question, Lear's book is a remarkable breakthrough; it comes close to raising the crucial ontological question of how to deal with the total collapse of a culture, and it may well become a classic by starting a conversation on the question: How should we live when our own culture is in the process of actually collapsing?
\end{abstract}

Lear suggests that

[w] hat would be required ... would be a new Crow poet: one who could take up the Crow past and-rather than use it for nostalgia or ersatz mimesisproject it into vibrant new ways for the Crow to live and to be. (p. 51)

Later Heidegger had a similar suggestion for us and I try to spell it out briefly.

Keywords World-collapse · Ontological · Heidegger · Nietzsche · Woodstock

This article was written in collaboration with Sean D. Kelly.

H. L. Dreyfus $(\bowtie)$

Department of Philosophy, University of California, 314 Moses Hall 2390,

Berkeley 94720-2390, CA, USA

e-mail: dreyfus@berkeley.edu 
Cultural devastation, and the proper response to it, is the central concern of Radical Hope. By cultural devastation, Jonathan Lear means something radical. At the extreme it is the loss of a culture's very way of life: a loss of its ability to do what is meaningful and admirable, the organizing practices that motivate the ambitions and despairs of its people, its unexamined sense of what constitutes a life well-lived. Lear addresses the problem of cultural devastation through the case of the Crow Indians, who faced the destruction of their way of life at the hands of the American government in the mid to late 19th century. But the book is important for us today not just as a study of what happened to the Crow. Indeed, Lear claims that it is a transcendental truth about all cultures that they are vulnerable to the disaster to which the Crow nearly succumbed.

Lear says, rightly, that the loss of a whole way of life is deeper and more devastating than the loss of any particular set of practices or values. He would presumably agree that when Athens succumbed to Sparta after nearly 30 years of wasting war, and its direct democracy was suspended in favor of an oligarchical rule of tyrants, this was not yet a loss on the order which Lear envisages. Likewise, when Lincoln's Union States finally overcame the Confederacy, the South was faced with the challenge of continuing life in the absence of what were arguably some of their most cherished social practices and distinctions. But what was at stake in that conflict too was not a loss of the radical kind in question. In both these cases cultures suffered great devastation, and it was only with courage and determination that they were able to rebuild functioning and healthy societies. But what they did not face is the complete loss of meaning of the sort that Lear describes, a loss so total that in the words of the Crow Chief, Plenty Coups, "After that, nothing happened." In a word, which Lear borrows from Heidegger, the loss is ontological rather than merely political or social. According to Lear, what it meant to be a Crow had become unintelligible. As he puts it, "planting a coup-stick lost intelligibility." 1

But there seems some uncertainty in Lear's book as to how total the annihilation was. This is reflected in a wavering over the difference between a culture's way of life becoming impossible and its way of life becoming unintelligible-I will call this the difference between cultural devastation and cultural collapse. A dramatic case of finding a way of life impossible would be losing the person you love; whereas a case of unintelligibility would be falling out of love and so finding it incomprehensible that you ever found the person you once loved loveable. Since the old practices still make sense, the victims of the first type of case risks succumbing to nostalgia-it was so great being together, if only I could get her back; - whereas the second type of case would make getting the loved one back an embarrassment.

Lear notes a related ambiguity when he introduces his important idea of impossibility but he immediately covers it up by equivocating on the notion of a practice ceasing to make sense. He tells us that:

everything in tribal life was organized around hunting and war-but hunting and war had become impossible. There is crucial ambiguity in this claim that

\footnotetext{
1 John Lear, Radical Hope (Cambridge, MA: Harvard University Press, 2006, p. 51). All subsequent references are to this book.
} 
is easily overlooked. When we say "It is no longer possible to go to war" or "It is no longer possible to hunt buffalo" we might mean either:

Circumstances are such that there is no practical possibility of our performing those acts

or

The very acts themselves have ceased to make sense (p. 38).

Here is how Lear explains the ambiguity:

By the way of analogy, consider a person who goes into her favorite restaurant and says to the waiter, "I'll have my regular, a buffalo burger medium rare." The waiter says, "I'm sorry madam, it is no longer possible to order buffalo; last week you ate the last one. There are no more buffalo. I'm afraid a buffalo burger is out of the question." Now consider a situation in which the social institution of restaurants goes out of existence. For a while there was this historical institution of restaurants-people went to special places and paid to have meals made and served to them-but for a variety of reasons people stopped organizing themselves in this way. Now there is a new meaning to "it is no longer possible to order buffalo": no act could any longer count as ordering. (p. 38)

What Lear's distinction covers up is that both the above cases are forms of impossibility. Neither is a case of unintelligibility. One can see this by noting that in both of Lear's cases one can long nostalgically for the good old days when there were buffalo, buffalo burgers, and restaurants to serve them. For the case to become one of unintelligibility, which is the case relevant to culture collapse, one would have had to have been a buffalo burger devotee building one's life around buffalo burgers and then be born again as a crusading vegetarian who finds it disgusting, indeed, inconceivable that anyone should want to order a buffalo burger.

The question is: on Lear's interpretation, when Plenty Coups dramatically buries his coup-stick - symbol of the old warlike virtues - in the grave of the unknown soldier, is he saying that a life of heroic fighting is no longer possible, or has it become unintelligible to him why anyone would fight over territory and, in the process, try to humiliate their fellow human beings by scalping them? In the case of the impossibility of the old way of life, we can imagine that Plenty Coups had gone through grief and interiorized important aspects of his former way of life so that, on the background of the old way of life, he is able to mourn and move on to new Crow-like things.

As Lear puts it:

What was he doing with his warbonnet and coup-stick? Many meanings might attach to such a gesture; but in the context of the current discussion one meaning suggests itself: he is burying them. On this interpretation, Plenty Coups is serving as a remarkable kind of witness: he is making the end of a way of life in which the coup-stick and warbonnet had integral roles. They have reached the end of their traditional lives, and it is time to locate them in a 
new ritual, that of remembering and mourning the valiant deeds of Indians past. (p. 33)

This was presumably the case with the Athenians and with the Southerners. They presumably saw important aspects of their old way of life as gone for good, and nonetheless managed to find new meaningful opportunities for going on as Athenians or Southerners while presumably reminiscing about the good old days. But, on Lear's interpretation, for the Crow something more radical-something ontological-had occurred. When the buffalo went away things ceased to happen.

Humans are by nature cultural animals: we necessarily inhabit a way of life that is expressed in a culture. But our way of life-whatever it is-is vulnerable in various ways. And we, as participants in that way of life, thereby inherit a vulnerability. Should that way of life break down, that is our problem. The suggestion I want to explore ... is that if our way of life collapsed, things would cease to happen. (p. 6)

So Lear presumably should be asking the radical ontological question: when the cultural collapse is such that the old way of life has become not only impossible but retroactively unimaginable,--when nothing one can do (or did) makes sense anymore,--how does one go on? What resources did Plenty Coups and his fellow Crow Indians have that enabled them to come up with a radically different way of life in which things once again could happen? What is the phenomenon Lear points to with the intriguing term, radical hope? In raising this question, Lear's book is a remarkable breakthrough; it comes close to raising the crucial ontological question of how to deal with the total collapse of a culture, and it may well become a classic by starting a conversation on this subject vis-à-vis our own culture.

But if Plenty Coups found the old way of life no longer intelligible so that grieving for it, longing for it, and reconnecting with it was impossible, what could he do? Lear holds that, thanks to several prophetic dreams and radical hope, Plenty Coups was able to find a new way of life for himself and his fellow members of the Crow Nation.

Appreciating Lear's book requires understanding his interpretations of Plenty Coups's dream that tells him to listen to the Chickadee. The young Plenty Coups who has the dream is told by his elders that "The Chickadee is a good listener. Nothing escapes his ears which he has sharpened by constant use. Whenever others are talking together of their successes and failures, there you will find the Chickadee-person listening to their words. But in all his listening he tends to his own business. He never intrudes, never speaks in strange company, and yet never misses a chance to learn from others"(p. 70). Plenty Coups's trust in the Chickadee is supposed to be an example of the radical hope that enabled him to save the Crows from the drunken disillusion that affected other Indian tribes such as the Sioux. According to Lear, among other things, this dream saves Plenty Coups from the Sioux Chief Sitting Bull's nostalgia.

On Lear's reading, the Chickadee's advice amounts to listening even to the enemy. Following that advice, Plenty Coups was able to stay open and find new meaningful possibilities for action. He turns to raising prize winning vegetables, 
gets baptized and married in the church, and even advises the Crow young men to fight with the US Army against other Indian tribes, and to fight heroically on the U.S.'s side in World War I. Granted this saved the Crow from the devastation that destroyed the Sioux; it does not seem like radical hope. It looks to me like Plenty Coups was a realistic opportunist made a hero by Lear's poetry and moral luck. But as Lear says, we are concerned here not with the facts but with the possibilities. The test, then, would be to see what radical hope would look like in the case of our own culture.

Although Lear says that the case of the Crow is relevant to us, I would like to suggest that he thinks this for the wrong reasons. In particular, Lear argues that vulnerability to the devastation of whatever makes our life meaningful is something that "we all share simply in virtue of being human" (p. 8). Lear tells us the possibility that things will cease to happen "is a possibility we all must live with-even when our culture is robust, even if we never have to face it becoming actual ..." (p. 9)

This vulnerability to devastation is an important existential condition, and I'll come back to it in a moment. But I want to suggest that it doesn't capture the uniqueness of our current cultural situation. Lear is correct to claim that the actual devastation of our civilization is "one of life's remoter ... possibilities" (p. 105). But our culture is not only vulnerable to devastation in principle, it may well be collapsing right now. If Nietzsche is right, our modern understanding of ourselves is suffering a breakdown in the wake of the death of the monotheistic God. Since all our practices and valuations were grounded on such a God, the realization that that God is dead will result in what Nietzsche calls a cataclysm. Indeed, if Nietzsche is right, our Judeo-Christian culture is becoming not just impossible but unintelligible.

So we need to sharply distinguish two questions both of which are important and both rarely discussed.

1. How should one live in the face of one's vulnerability, that is in the face of the possibility of cultural devastation?

And,

2. How should one live when one's culture is in the process of actually collapsing?

Heidegger has considered this first question in his discussion of death in Being and Time. His view is interesting although not very radical, but since Lear draws on Heidegger, I'll touch on Heidegger's view for a moment here.

Heidegger describes a way of life in the face of our existential vulnerability that is between Kierkegaard's and Nietzsche's proposals as to how to deal with possible world collapse. Kierkegaard holds that, to avoid despair, each individual must make an unconditional commitment and stick to it no matter what. Nietzsche thinks that "commitments are prisons" and we should be constantly reinventing ourselves. Heidegger combines these views and says that in the face of our ontological vulnerability - the possibility of no more possibilities — we should live a life that is steadfast and yet flexible. That is, we should avoid the twin dangers of fanaticism and nihilism. 
If one finds it hard to see what Heidegger's proposal comes to, John Haugeland, whom Lear thanks in his acknowledgements, offers a helpful analogy with Kuhn's account of science. Particular scientific world-views are subject to collapse. Heidegger sees that the serious scientist doing normal science must devote himself to the current science and try to account for current anomalies in the way that that science requires. But the authentic scientist is open to anomalies, and if the anomalies pile up, he is flexible enough to give up the current science as a whole and adopt a revolutionary new one. As Haugeland puts it summing up Heidegger response to our vulnerability to world collapse: we should stick with things but not get stuck with them.

In our current collapsing culture, sticking with them might be the nostalgic approach that attempts to revive the classic virtues, or, perhaps, hold onto Kantian autonomy. In this connection T.S. Elliot's speaks of “These fragments I have shored against our ruin." Or in more contemporary terms, Dylan tells us to "strengthen the things that remain." But on the view of total collapse that Heidegger and Lear are considering such nostalgia for what is no longer possible would be irrelevant. Indeed, with the death of God, saving what remains of the old worldview is no longer even intelligible.

So the harder question is the second question. What if nothing that remains is any longer meaningful? How could the Crow salvage anything? If so, what? If, "after the buffalo went away" "nothing happened," how were Plenty Coups and his Crow followers able to begin anew? What are the resources for radical cultural renewal?

Lear holds that this is where we must bring in radical hope. He tells us:

Plenty Coups responded to the collapse of his civilization (not just its destruction) with radical hope. What makes this hope radical is that it is directed toward a future goodness that transcends the current ability to understand what it is. Radical hope anticipates a good for which those who have the hope as yet lack the appropriate concepts with which to understand it. (p. 103)

[T] he commitment is only to the bare possibility that, from this disaster, something good will emerge: the Crow shall somehow survive. Why that will be or how that will be is left open. The hope is held in the face of the recognition that, given the abyss, one cannot really know what survival means. (p. 97)

But this seems too empty to be any help. Plenty Coups is supposed to provide an illustration of such hope but, as I have said, I don't see what new way of acting made life meaningful to Plenty Coups. It looks like he just picked up at random our current practices, like that of agriculture, and then ran with them.

Lear has another suggestion that has more substance.

What would be required, though, would be a new Crow poet: one who could take up the Crow past and-rather than use it for nostalgia or ersatz mimesisproject it into vibrant new ways for the Crow to live and to be. (p. 51)

By drawing on Crow "traditions in novel ways in the face of novel challenges" (pp. 65-66), "Plenty Coups helped to create a space in which traditional Crow values can be preserved in memory, transmitted to a new generation, and, one hopes, renewed in a new historical era" (p. 146). 
But how could one take up traditional values that have become unintelligible except by a self-deluded form of nostalgia. Indeed, to Lear's credit we see no examples in his book of Plenty Coups taking up traditional practices and reinterpreting them.

In his later writings, Heidegger has a helpful answer to how a cultural world could be radically reborn. He holds that, in response to total world collapse one must become sensitive to marginal practices. This would not be nostalgia because these practices would not have been the one's that, until the devastation, gave cultural life its meaning. Rather, precisely because such practices would not have been central to the meaning of the past way of life they could survive the collapse. I would interpret the Chickadee as trying to tell Plenty Coups (and Jonathan Lear) to be on the look out for such marginal practices. Radical world rebirth can take place if and only if one can make some marginal practices central and in their light see the current central practices that have become meaningless or at best marginal.

Having asked Lear for more phenomenological details about how radical hope is supposed to work, I feel obliged to offer an example of the Heideggerian view. One could view Woodstock as a failed attempt to shift the marginal practices to the center. In the sixties, Bob Dylan, the Beatles, and other rock groups became for many the articulation of a new understanding of what really mattered. This new understanding almost coalesced into a cultural paradigm in the Woodstock music festival of 1969, where people actually lived for a few days in an understanding of being in which mainline contemporary concerns with order, sobriety, willful activity, success, and efficient control were made marginal and subservient to pagan practices, such as receptivity, enjoyment of nature, dancing, Dionysian ecstasy, and non-exclusive love of one's neighbor. Technology was not smashed or denigrated, rather all the power of electronic communications was put at the service of the music which focused the above concerns.

If enough people had recognized in Woodstock what they most cared about and recognized that many others shared this recognition, a new understanding of being might have been focused and stabilized. Of course, in retrospect it seems to us who are still in the grip of the technological understanding of being that the concerns of the Woodstock generation were not organized and total enough to sustain a culture. Still we are left with a hint of how a new cultural paradigm might work. This helps us understand that we must foster our receptivity and preserve the endangered species of pre-technological practices that remain in our culture, in the hope that one day they will be pulled together in a new paradigm - a paradigm rich enough and resistant enough to give a new meaningful direction to our lives.

If this Heideggerian reading of the Chickadee is right, Lear missed an opportunity to show that Plenty Coups's conversion to agriculture was neither eclectic nor a sell out. Lear mentions in passing a Crow account that claims that agriculture was once the central practice for the Crow. The account tells us: "The Crows began as an agricultural and quasi-sedentary tribe. They became a nomadic, hunting tribe, and today they constitute a rural community ... " (p. 99). Perhaps, agriculture remained a set of marginal practice for the Crow and they led Plenty Coups to "avidly take up farming and urge other members of the tribe to do so" (p. 5) as a way of going forward by going back. 
Heidegger would say that Homer's polytheistic practices that focus on the importance of moods such as the erotic with Aphrodite and aggression with Aresmoods that have been eclipsed by monotheism - might, if made central once again, suggest an answer to our current nihilism. Heidegger gets his idea of the return of the gods from the poet, Holderlin. Our American Holderlin is Herman Melville. In Moby Dick Melville explores the danger of the monotheistic monomania of Ahab, and counters that our salvation lies in the hands of some "poetical nation" that can "lure back to their birthright" those ancient gods, and "livingly enthrone them again in the now egotistical sky; on the now undaunted hill." Holderlin, Melville, and Heidegger all hold that only such a return to something from our past that is currently marginal for us can save us from the twin temptations of nihilism and fanaticism that together threaten our modern existence.

Thanks to Jonathan Lear we are all solicited to engage in the life and death cultural conversation that he opens up with this book, Radical Hope.

Open Access This article is distributed under the terms of the Creative Commons Attribution Noncommercial License which permits any noncommercial use, distribution, and reproduction in any medium, provided the original author(s) and source are credited. 